\title{
Anatomic Variations of the Hand Extensor Muscle Tendons
}

\author{
Elin Ekstensor Kas Tendonlarındaki Anatomik Varyasyonlar
}

\section{Yadigar Kastamoni Yaşar ${ }^{1}$, Afitap Anıl ${ }^{1}$, Feza Anıl ${ }^{2}$, Menekşe Kastamoni ${ }^{3}$, Tuncay Peker ${ }^{1}$}

${ }^{1}$ Gazi University, Faculty of Medicine, Department of Anatomy, Ankara, Turkey

${ }^{2}$ Selçuk University, Akşehir Kadir Yallagöz School of Health, Konya, Turkey

${ }^{3}$ Uludağ University, Faculty of Medicine, Department of Plastic, Reconstructive and Aesthetic Surgery, Bursa, Turkey

\section{ABSTRACT}

Variations of muscles on the dorsal aspect of the forearm are seen very common. These variations can be symptomatic but generally they are diagnosed incidentally. On the posterior compartment of forearm, extensor carpi radialis brevis related to abduction of the wrist and extensor digitorum related to extension of the wrist and fingers. This case report showed rare variations of extensor carpi radialis brevis and extensor digitorum muscles. During routine dissections of the extensor compartment of the forearm for anatomy education, it was observed that extensor carpi radialis brevis muscle had an accessory head which attached to dorsum and proximal phalanx of the index finger. Besides, it was found that extensor digitorum muscle divided into three tendons distally. When we followed these tendons, it was observed that tendon of index finger was absent and other three tendons went to middle, ring and little fingers. Accessory muscles located on the extensor compartment of the forearm are seen common. They can be reason of the symptoms of the nerve entrapment. Besides, these unusual muscles may confuse radiologists, surgeons and anatomists. In order to prevent diagnostic errors and avoid surgical complications, these anatomical variations should be well-known.

Key Words: Anatomic variations, accessory head, extensor carpi radialis brevis, extensor digitorum, tendon variations

\section{ÖZET}

Elin dorsal yüz kaslarındaki varyasyonlar yaygındır. Genellikle bu varyasyonlar ameliyat esnasında tesadüfen bulunmakta, fakat bazen semptomatik de olabilmektedirler. Önkolun posterior kompartımanında, musculus extensor carpi radialis brevis bileğin abduksiyonunda görevli iken, musculus extensor digitorum bilek ve parmakların ekstensiyonundan sorumludur. Bu vakada, musculus extensor carpi radialis brevis ve musculus extensor digitorum'un nadir rastlanan varyasyonları gösterildi. Anatomi eğitimi için gerçekleştirilen ön kolun extensor kopartmanının rutin diseksiyonu sırasında, musculus extensor carpi radialis brevis'ten köken alan ve işaret parmağın proksimal falanksının dorsumuna bağlanan aksesuar kas gözlendi. Bunun yanı sıra, musculus extensor digitorum, distalde üç tendona ayrılmakta idi. Bu tendonlar incelendiğinde, işaret parmağı tendonunun olmadığı ve diğer üç tendonun orta, yüzük ve küçük parmağa gittiği gözlendi. Önkol ekstensor kompartımanında yer alan aksesuar kaslar çok yaygındır. Bunlar sinir sıkışması semptomlarının sebebi olabilirler. Ayrıca, bu anormal kaslar radyologların, cerrahların ve anatomistlerin kafasını karıştırabilir. Tanı hatalarını önlemek ve cerrahi komplikasyonlardan kaçınmak için, bu anatomik varyasyonlar iyi bilinmelidir.

Anahtar Sözcükler: Anatomik varyasyonlar, aksesuar baş, musculus extensor carpi radialis brevis, musculus extensor digitorum, tendon varyasyonları

Geliş Tarihi: $\quad 30.11 .2016$

Kabul Tarihi: 23.06.2017

\section{INTRODUCTION}

Extension of the fingers and the wrist is carried out by the muscles on the dorsal aspect of the forearm (1). Variations of these muscles are seen very common. Generally, these variations are often diagnosed incidentally during surgery, but sometimes they can be symptomatic. Knowledge of such variations is important, especially in clinical practice such as surgical operations.

Extensor carpi radialis brevis originates from the lateral epicondyle of the humerus via a tendon and it shares this tendon with other forearm extensor muscles. The belly of the muscle ends in a flat tendon at about mid-forearm. This tendon passes under the extensor retinaculum and then it is attached to the dorsal surface of the base of the third metacarpal on its radial side, distal to its styloid process of radius, and on adjoining parts of the second metacarpal base. The extensor carpi radialis brevis is innervated by the posterior interosseous nerve (2).
Extensor digitorum originates from the lateral epicondyle of the humerus via the common extensor tendon. Distally, it divides into four tendons. These tendons pass under the extensor retinaculum (2). Each of these tendons goes to a finger: the index, the middle, the ring and the little fingers (3). The extensor indicis tendon accompanies to the tendon of the index finger of the extensor digitorum. The extensor indicis tendon lies at its ulnar side. Similarly, the extensor digiti minimi tendon accompanies to the tendon of the fifth finger of the extensor digitorum and lies at its ulnar side (2).

The anatomic variations and prevalence of the extensor muscle tendons have been reported in many studies $(3,4)$. Similarly to these studies, in this case report, we showed rare variations of extensor carpi radialis brevis and extensor digitorum muscles. 
At Gazi University, Department of Anatomy, Faculty of Medicine, variations of extensor carpi radialis brevis and extensor digitorum were found in right upper extremity of a 66-years-old male cadaver, during routine dissections of the extensor compartment of the forearm for anatomy education. The incision was performed on right forearm from interepicondylar line to extensor retinaculum. Skin, subcutaneous fat, superficial and deep fascias were removed and extensor muscles were exposed. After extensor muscles were defined, variations of the extensor carpi radialis brevis and extensor digitorum were identified. Because of determination of these variations, dorsum of the hand was also dissected.

In our case, it was observed that extensor carpi radialis brevis muscle had an accessory head. Tendon of this accessory head was pursued and it was confirmed that it attached to dorsum and proximal phalanx of the index finger. In addition to this variation, we found that extensor digitorum muscle divided into three tendons distally. When we followed these tendons, it was observed that tendon of index finger was absent and other three tendons went to middle, ring and little fingers (Figure 1 and 2).
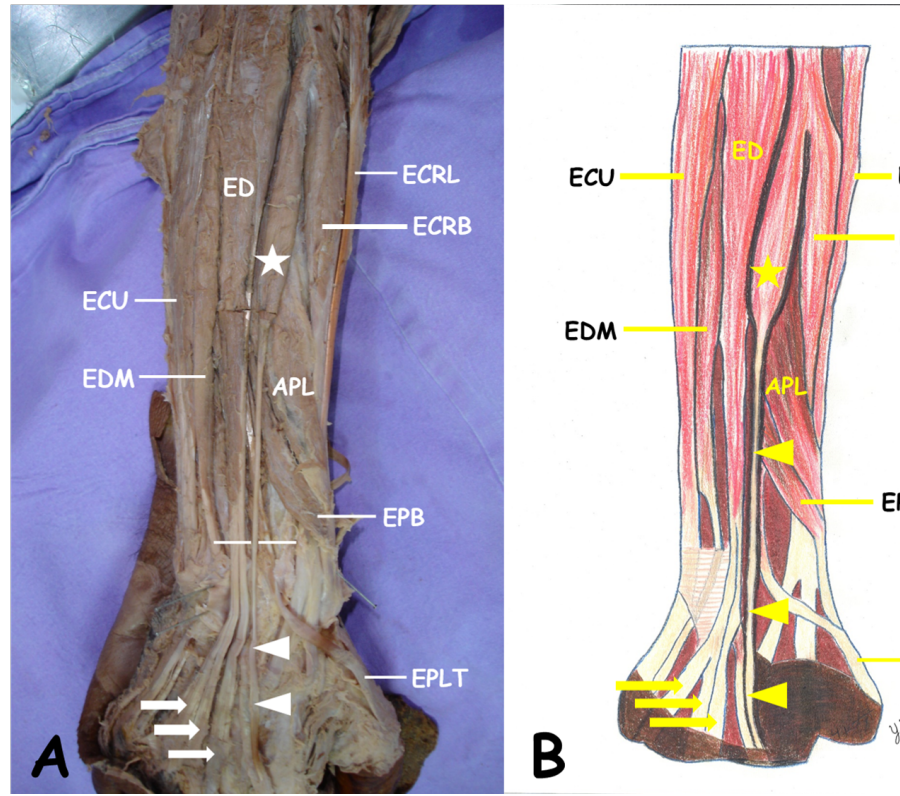

Figure 1A. Accessory muscle originated from extensor carpi radialis brevis (star) and variation of tendons of extensor digitorum muscle (arrows). Figure 1B. Schematic drawing of figure $1 \mathrm{~A}$. ECRL extensor carpi radialis longus muscle, ECRB extensor carpi radialis brevis muscle, ED extensor digitorum muscle, ECU extensor carpi ulnaris muscle, EDM extensor digiti minimi muscle, APL abductor pollicis longus muscle, EPB extensor pollicis brevis muscle, EPLT tendon of extensor pollicis longus muscle, arrow heads tendon of accessory muscle.

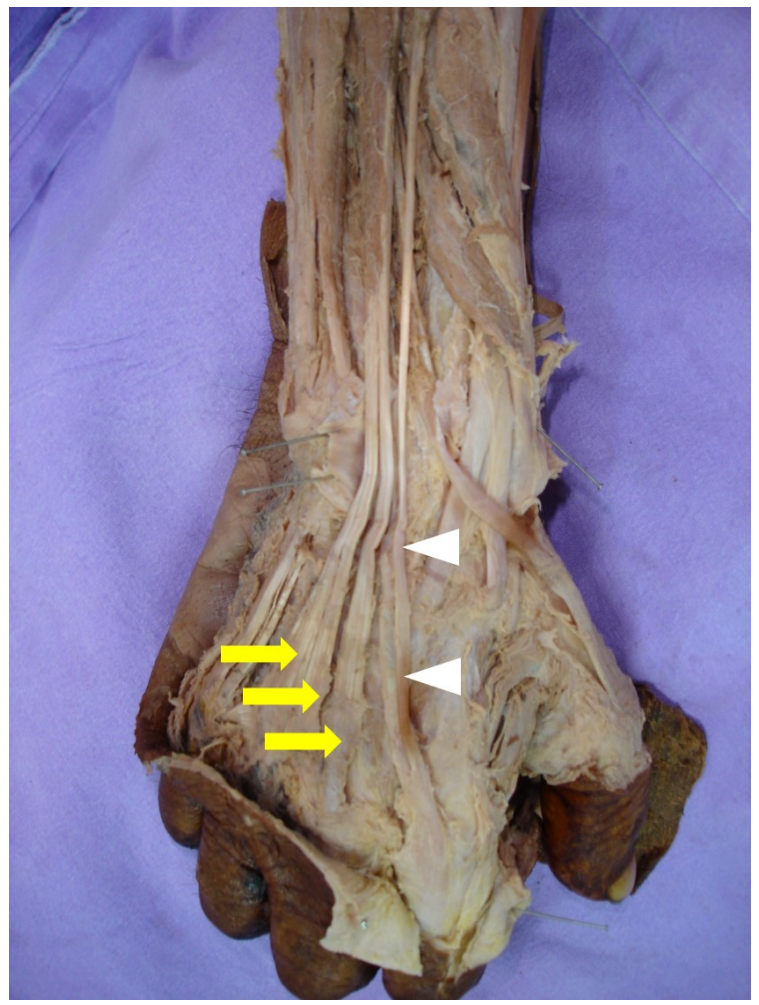

Figure 2. Tendons of extensor digitorum muscle (arrows) and accessory muscle (arrow heads)

\section{DISCUSSION}

Extensor carpi radialis brevis related to abduction of the wrist and extensor digitorum related to extension of the wrist are superficial muscles on the posterior compartment of forearm (1). In this region, variations are seen very common. In order to understand anatomical variations, knowledge of human embryology is important. In the forearm, the precursor extensor muscle mass differentiates into a radial portion. Then, this radial portion divides into superficial and deep portions. Extensor digitorum, extensor carpi ulnaris, and extensor digiti minimi muscles are originated from the superficial portion while abductor pollicis longus, extensor pollicis brevis, extensor pollicis longus and extensor indicis muscles are originated from the deep portion (5). Developmental defect in different stages of gestation is one of the reasons of the anatomical variations. Besides, various changes of extensor limb myotomes involved in the transformation of the somatic layer of lateral mesoderm; such as regression, retention, or reappearance may be the cause of variations of the tendons (6).

Different variations related to tendon of the extensor digitorum and additional head of the extensor carpi radialis brevis were reported by various authors. Arora et al. (7) reported same variation observed in our case. In their study, researchers observed that the extensor carpi radialis brevis had an accessory belly attaching to the dorsum of index finger. Besides, they stated that extensor digitorum showed trifurcation distally. Similarly, Melling et al. (8) also found an accessory muscle arised from the extensor carpi radialis brevis and attached to dorsum of the index finger in both forearms of a 55-years-old male cadaver. Agarwal and Tirthani (4) examined extensor digitorum tendons and determined absence of the tendon of the index finger in one specimen in 120 upper extremities in their study about the long extensor tendons of the finger.

Gumusalan et al. (9) reported an accessory muscle arised from extensor carpi radialis brevis and attached to second metacarpal bone. Vessal and Rai (1) detected an accessory extensor carpi radialis brevis on the right forearm of a 39-years-old Caucasian female patient.

Location of the extensor tendons is very superficial so that subcutaneous tissue protection is very inadequate. Therefore, the tendons of the extensor muscles are more frequently injured than the tendons of flexor muscles (10). At origin and insertion of muscles, multiple variations are common. Knowledge of the existence of these variations is necessary for radiologists to help to formulate a differential diagnosis of cases (1).

Accessory muscles located on the extensor compartment of the forearm are seen common. They can be reason of the symptoms of the nerve entrapment (1). Besides, these abnormal muscles may confuse surgeons and anatomists. In order to prevent diagnostic errors and avoid surgical complications, these anatomical variations should be well-known.

\section{Conflict of interest}

No conflict of interest was declared by the authors.

\section{REFERENCES}

1. Vessal S, Rai SB. Accessory extensor carpi radialis brevis muscle, a pseudomass of the distal forearm: ultrasound and MR appearances -case report and literature review. Clin Radiol 2006; 61: 442-5.

2. Standring S. Gray's Anatomy. 39th ed. London: Elsevier Churchill Livingstone; 2005.

3. Yammine K. The prevalence of the extensor digitorum communis tendon and its insertion variants: A systematic review and meta-analysis. Clin Anat 2014; 27: 1284-90.

4. Agarwal $P$, Tirthani $G$. Cadaveric study of the long extensor tendons of the finger over the dorsum of the hand. Eur J Anat 2011; 15: 129-35.

5. Abdel-Hamid GA, El-Beshbishy RA, Abdel Aal IH. Anatomical variations of the hand extensors. Folia Morphol (Warsz) 2013; 72: 249-57.

6. Celik $S$, Bilge $O$, Pinar $Y$, et al. The anatomical variations of the extensor tendons to the dorsum of the hand. Clin Anat 2008; 21: 652-9.

7. Arora J, Dave V, Kumar A, et al. Unusual architecture of extensor digitorum muscle of hand in conjunction with accessory belly of extensor carpi radialis brevis: a clinicoanatomical insight. Clin Ter 2013; 164: 31-3.

8. Melling $M$, Steindl $M$, Wilde $J$, et al. An anatomical variant of the extensor carpi radialis brevis muscle. Wien Klin Wochenschr 2001; 113: 960-3.

9. Gumusalan $\mathrm{Y}$, Kalaycioglu $\mathrm{A}$, Yazar $\mathrm{F}$, et al. Accessory extensor carpi radialis muscle and interconnecting muscular bundle. Acta Anat (Basel) 1997; 159: 57-60.

10. Tuncali D, Yavuz N, Terzioglu A, et al. The rate of upper-extremity deep-structure injuries through small penetrating lacerations. Ann Plast Surg 2005; 55: 146-8. 